\title{
EFFICIENCY OF TEMPORARY STORAGE OF GEOTHERMAL WATERS IN A LAKE SYSTEM: MONITORING THE CHANGES OF WATER QUALITY AND BACTERIAL COMMUNITY STRUCTURES
}

\author{
BARBARA SZIRÁNYI ${ }^{1}$, GERGELY KRETT ${ }^{1}$, TÜNDE KOSÁROS ${ }^{2}$, ENDRE JANURIK ${ }^{2}$, \\ FERENC PEKÁR ${ }^{2}$, KÁroly MÁrialigeti ${ }^{1}$ and ANDREA K. BORSOdi ${ }^{1 *}$ \\ ${ }^{1}$ Department of Microbiology, ELTE Eötvös Loránd University, Budapest, Hungary \\ ${ }^{2}$ Research Institute for Fisheries, Aquaculture and Irrigation, Szarvas, Hungary
}

(Received: 11 October 2016; accepted: 27 May 2017)

\begin{abstract}
Disposal of used geothermal waters in Hungary often means temporary storage in reservoir lakes to reduce temperature and improve water quality. In this study, the physical and chemical properties and changes in the bacterial community structure of a reservoir lake system in southeast region of Hungary were monitored and compared through 2 years, respectively. The values of biological oxygen demand, concentrations of ammonium ion, total inorganic nitrogen, total phosphorous, and total phenol decreased, whereas oxygen saturation, total organic nitrogen, $\mathrm{pH}$, and conductivity increased during the storage period. Bacterial community structure of water and sediment samples was compared by denaturing gradient gel electrophoresis (DGGE) following the amplification of the 16S rRNA gene. According to the DGGE patterns, greater seasonal than spatial differences of bacterial communities were revealed in both water and sediment of the lakes. Representatives of the genera Arthrospira and Anabaenopsis (cyanobacteria) were identified as permanent and dominant members of the bacterial communities.
\end{abstract}

Keywords: geothermal water, reservoir lake system, water quality, bacterial diversity, DGGE, temporal and spatial changes

\section{Introduction}

Nowadays, geothermal waters are used worldwide for energy. In the middle of the 20th century, several oil exploratory drillings made in the southeast region of Hungary resulted in finding high-temperature $\left(96^{\circ} \mathrm{C}\right)$ thermal waters under

\footnotetext{
*Corresponding author; E-mail: borsodi.andrea@ttk.elte.hu
} 
great pressure [1]. Following the establishment of thermal wells, these geothermal waters have been used for energy purposes, since their relatively high hydrocarbon content made the recreational utilization impossible.

Although the use of geothermal energy is considered environmentally friendly compared with fossil fuels, the disposal of used geothermal waters has not yet been satisfactorily solved in Hungary. The chemical composition of geothermal waters often differs markedly from the receiving waters [2], therefore, the direct drainage of used geothermal waters into freshwaters is not authorized. There are applicable procedures for the management of used thermal waters such as reinjection into the source medium, temporary storage in reservoir lakes, ionization, and ozone treatment $[3,4]$. Nevertheless, each of them has their own limitations. Reinjection of thermal waters to the aquifer layer could be a preferred solution because it provides adequate heat recovery and maintains the pressure in the reservoir. However, there is a possibility that the bedrock layers get damaged through time, e.g., due to high pressure used for reinjection and salt precipitation may alter the original composition of the sourced water [5]. Although increasing efforts are being made to the reinjection of used thermal waters in Hungary [4], a significant amount of the used thermal waters is redirected into a recipient natural water following temporary storage in reservoir lakes [6].

This study focused on a Hungarian reservoir lake system operating as cooling and temporary storage of used geothermal water. The studied reservoir lake system, consisting of four shallow and small lakes, was established between 1982 and 1985. As the lakes are gravitationally interconnected, they probably do not represent different levels in terms of the water recovery process.

Despite the fact that coordinated monitoring programs can facilitate the efficient environmental management, so far little is known about the spatial and temporal variability of bacterial communities of reservoir lakes used for temporal storage of geothermal water. Therefore, the aim of this study was to gain insight into the seasonal changes of the physical and chemical parameters as well as the bacterial community structures of the reservoir lake system. Another objective was to reveal and compare the water quality changes during the storage period in two different years in terms of weather conditions.

\section{Materials and Methods}

Description of the studied site, sampling, and studying the bacterial cell morphology

The studied reservoir lake system is located near Szarvas, a town in the southeast region of Hungary (Figure 1). Lakes BT1 and BT3 were formerly used as 

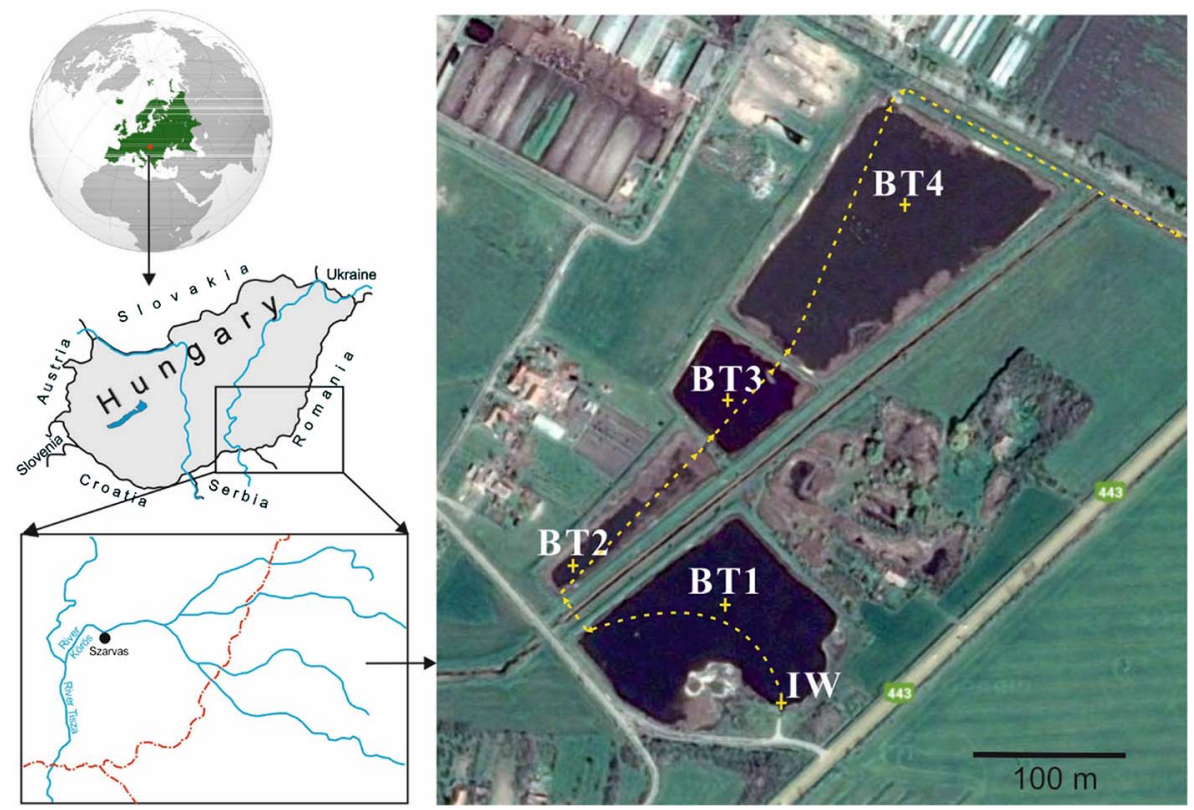

Figure 1. Location of the reservoir system in Europe and southeast region of Hungary. The studied four interconnected lakes are shown in the satellite image (source: Google Earth). (Arrows shown in the satellite image indicate the direction of the water flow and crosses indicate the sampling sites.)

clay mining pits, whereas BT2 and BT4 were created for being reservoir lakes. All four lakes are surrounded by a natural reed belt, but the second lake (BT2) has an almost complete reed coverage. They have a total area of $85,530 \mathrm{~m}^{2}$ and a total volume of $177,710 \mathrm{~m}^{3}$. The average depth of the lakes is between 2 and $3 \mathrm{~m}$, but in the third lake (BT3) the water depth can reach $5 \mathrm{~m}$. However, the water depth of the lakes changes between 0.5 and $5 \mathrm{~m}$ depending on the storage time. The used thermal water reaches BT1 and being redirected to natural waters from BT4, while it passes all lakes consecutively, they are interconnected through earthen channels (Figure 1). The amount of used geothermal water, entering the reservoir lake system, is equal to the amount of extracted well waters. The characteristics of the thermal water of the wells and the sourcing environment were studied and described by Németh et al. [1]. Nevertheless, the amount of the water led from the reservoirs to the recipient river Hármas-Körös is less, due to the evaporation during the storage period. The average residence time of the water in the reservoir lakes is 6 months in the summer period and minimum 2 months in the winter period depending on the volume of the used thermal water. The drainage of the stored thermal water into the river Hármas-Körös is permitted between October 15 and March 31, outside the vegetation period. 
The inflow water samples were collected in March and October 2012 into sterile bottles ( $2 \mathrm{~L}$, respectively) at the endpoint of the pipe transporting the used geothermal water into the first reservoir (46.855622 N, $20.584487 \mathrm{E})$. Lake water and sediment samples were taken from the same sites (BT1 $46.856410 \mathrm{~N}$, 20.583690 E; BT2 46.856733 N, 20.582102 E; BT3 46.858110 N, 20.583879 E; and BT4 46.859607 N, 20.586251 E) in March, July, and September 2012 and in April, July, and September 2013. Lake water samples (W1-W4) were collected into sterile bottles approximately $20 \mathrm{~cm}$ below the surface by immersion, $1 \mathrm{~L}$ per sample. Approximately $200 \mathrm{~g}$ of sediment samples (S1-S4) were taken into sterile glass containers from the $3-5 \mathrm{~cm}$ layer below the sediment surface using a Hargrave sampler. Samples were kept cool until the laboratory processing within $24 \mathrm{~h}$.

Morphology of planktonic bacterial cells in native preparations was observed using Nikon 80i microscope.

\section{Weather conditions during the examined years}

Region-specific weather data from the two studied years were obtained from the webpage of the Hungarian Meteorological Service [7] for every month respectively regarding the temperature and the precipitation. Data are shown in Figure 2 . The monthly mean temperature values in both years exceeded the longterm average, but differences were seen between the two studied years (Figure 2a): in 2012 winter was colder but March was relatively warm and dry, whereas in 2013 the same month was $5{ }^{\circ} \mathrm{C}$ colder and the precipitation was the highest during the whole examined period of 2 years (Figure $2 b$ ). This was the reason why a drainage of the whole reservoir system was necessary, and the sampling was rescheduled from March to April in 2013. In 2013, late spring and summer was few degrees colder on average than the previous year, and autumn cooling started earlier.

\section{Water quality measurements}

Water was checked for temperature, electric conductivity, $\mathrm{pH}$, and dissolved oxygen level with portable meters (WTW MultiLine P4 Universal Meter, Xylem Analytics, Weilheim, Germany). The water samples were analyzed for chemical oxygen demand (COD) according to the Macherey-Nagel Nanocolor COD 1500 method. The biological oxygen demand (BOD) was measured with WTW OxiTop system (Xylem Analytics, Weilheim, Germany). The inorganic nitrogen, the soluble reactive phosphorus and the total phenol concentrations were measured with Lachat QuikChem 8500 Flow injection analyzer (Lachat Instruments, 


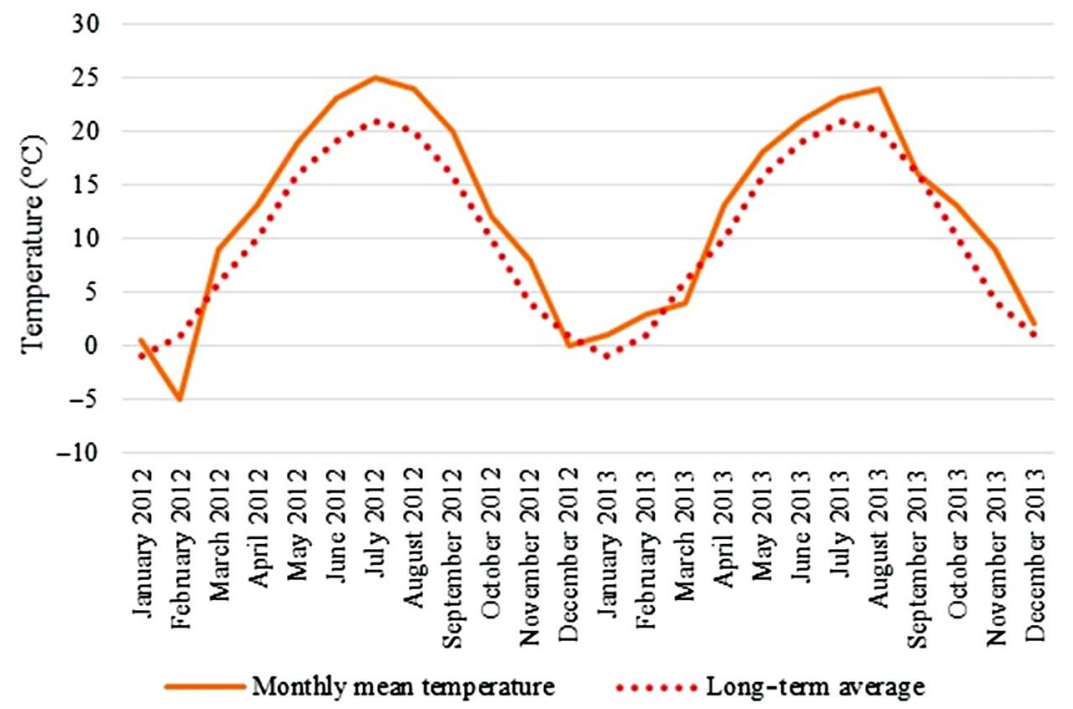

(a)

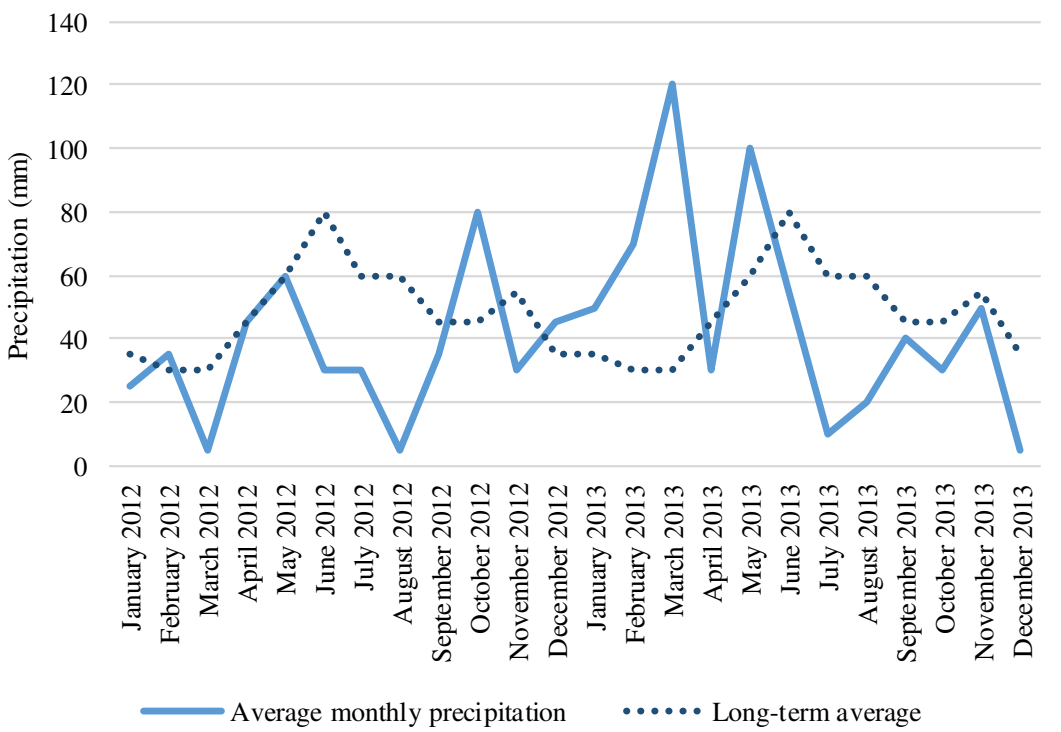

(b)

Figure 2. (a) The monthly temperature averages near Szarvas during the 2 years of investigation compared with the long-term temperature average in the region. (b) The monthly precipitation average near Szarvas during the two whole years of the investigation compared with the long-term precipitation average in the region. Data were obtained from the webpage of the Hungarian

Meteorological Services (publicly available) 
Loveland, CO, USA). The organic nitrogen and phosphorous concentrations were determined by colorimetric analysis using a Lange Ganimede $\mathrm{N}$ and $\mathrm{P}$ analyzer (Hach, Manchester, UK). The analysis of polycyclic aromatic hydrocarbons was performed using gas chromatography-mass spectrometry. The oxidation-reduction potential $(\mathrm{mV})$ of the sediment samples was determined using Cole-Parmer Model \#59002-10 pH/mV/ $/{ }^{\circ} \mathrm{C}$ Meter (Cole-Parmer, Vernon Hills, IL, USA). Hungarian Standard Methods (MSZ) were applied to measure the main components of water quality: pH (MSZ 1484-22:2009), dissolved oxygen (MSZ EN 25814:1998), redox potential (MSZ ISO 5667-10:1998), electric conductivity (MSZ EN 27888:1998), COD (MSZ ISO 6060:1991), BOD (MSZE 21420-9:2004), ammonium-nitrogen (MSZ EN ISO 11732:2005), total nitrogen (MSZ EN ISO 11905-1:1998), total organic nitrogen (MSZ 12750-20:1972), total inorganic nitrogen (MSZ 1275020:1972), total dissolved solids (MSZ 260-3:1973), orthophosphate (MSZ EN ISO 15681-1:2005), total phosphorus (MSZ EN 1189:1998), and total phenol (MSZ EN ISO 14402:2000). In this study, water quality was evaluated in accordance with the Hungarian Standard Methods for the Water Quality of Surface Waters (MSZ 12749:1993).

Sample preparation, community DNA extraction, and polymerase chain reaction (PCR) amplification

According to the sample types, $1,500 \mathrm{ml}$ of inflow water and $10-50 \mathrm{ml}$ of lake water were filtered through $0.2 \mu \mathrm{m}$ pore diameter polycarbonate filters (ME 25/21 0.2 STL, Whatman, Maidstone, UK). Approximately 4-5 g of each sediment sample was compacted by centrifugation (14,000 rpm, $2 \mathrm{~min})$.

Community DNA extraction from the compacted samples was performed using the PowerSoil ${ }^{\circledR}$ DNA Isolation Kit (Mo Bio Laboratories Inc., Carlsbad, CA, USA) following the manufacturer's protocol.

The 16S rRNA coding region of the DNA was amplified in two consecutive PCR steps. The first reaction was accomplished with 27F (5'-AGAGTT TGATCMTGGCTCAG-3') [8] and 1401R (5'-CGGTGTGTACAAGACCC-3') primers [9] and the second (semi-nested PCR) with a GC-clamped 27F (5'-CGCCCGCCGCGCGCGGCGGGCGGGGCGGGGGCACGGGGGAGAGT TTGATCMTGGCTCAG-3') and 519R (5'-ATTACCGCGGCTGCTGG-3') primers [10]. The following temperature protocol was used for both PCR: initial denaturation at $98^{\circ} \mathrm{C}$ for $3 \mathrm{~min}$, followed by 32 cycles of denaturation at $94{ }^{\circ} \mathrm{C}$ for $30 \mathrm{~s}$, annealing at $52{ }^{\circ} \mathrm{C}$ for $30 \mathrm{~s}$, elongation at $72{ }^{\circ} \mathrm{C}$ for $90 \mathrm{~s}$, and a final extension at $72{ }^{\circ} \mathrm{C}$ for $10 \mathrm{~min}$. The same temperature profile was applied during the seminested PCR, except that the initial denaturation was at $96{ }^{\circ} \mathrm{C}$ for $30 \mathrm{~s}$. 
Denaturing gradient gel electrophoresis (DGGE) and $16 S$ rRNA gene sequencing

The DGGE was performed using an Ingeny PhorU system (Ingeny International, Goes, The Netherlands). PCR products were loaded onto $7 \%$ polyacrylamide gel, which contained $40 \%-60 \%$ denaturing gradient of urea and formamide. Electrophoresis was performed for $14.5 \mathrm{~h}$ at $120 \mathrm{~V}$ and at $60^{\circ} \mathrm{C}$ in $1 \% \mathrm{TAE}$ buffer. The DGGE gels were stained with ethidium bromide and photographed on a UV transillumination table. The DGGE profiles were analyzed using the TotalLab (TL120) v2006 software (Nonlinear Dynamics Inc., Newcastle upon Tyne, UK).

Discrete bands were cut from the gel with a sterile scalpel. DNA was extracted by adding $30 \mu \mathrm{l}$ ultraclean water to the gel pieces and incubating them overnight at $4{ }^{\circ} \mathrm{C}$, followed by centrifugation at $3,000 \mathrm{rpm}$ for $5 \mathrm{~s}$.

The identification of bacterial taxa representing the DGGE bands was based on the sequence homology of the 16S rRNA gene, amplified by PCR as described above for the first PCR. The PCR amplicons were sequenced with automatized Sanger-method at LGC Genomics (Berlin, Germany). Chromatograms were edited by Chromas Lite 2.1.1 software (Technelysium Pty Ltd, Brisbane, Australia). Identification was performed using the database of the EzTaxon-e server [11] and the NCBI database [12]. DNA sequences were uploaded to the GenBank database and can be found under the accession numbers LN794643-LN794664.

\section{Results and Discussion}

\section{Evaluation of the physical and chemical parameters}

To assess the changes of the studied reservoir system, a comparison was made between our findings and the regulations of the Hungarian Standard Methods for the Water Quality of Surface Waters (MSZ 12749:1993). The assessment of the physical and chemical parameters was based upon the four different groups: oxygen balance, nutritional factors, organic micropollutants, and others. The classification principles and the limit values regarding the different water quality classes are indicated in Supplementary Tables I and II.

According to the dissolved oxygen values (Figure 3a), lake BT4 was aerobic throughout the studied times, except for April 2013, following an inland water flood that occurred due to the unusually high precipitation in March. The impact of the heavy spring rains could also be detected in July 2013 in the first three lakes (BT1-BT3), the water of these lakes was almost anoxic. However, by the end of the storage period, all four lakes reached "good water quality" in both 


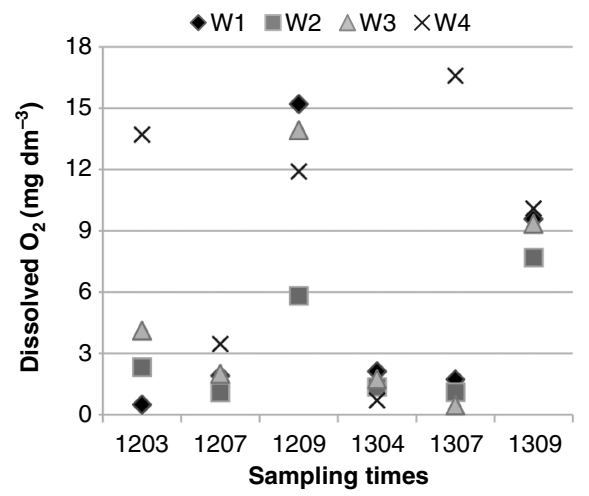

(a)

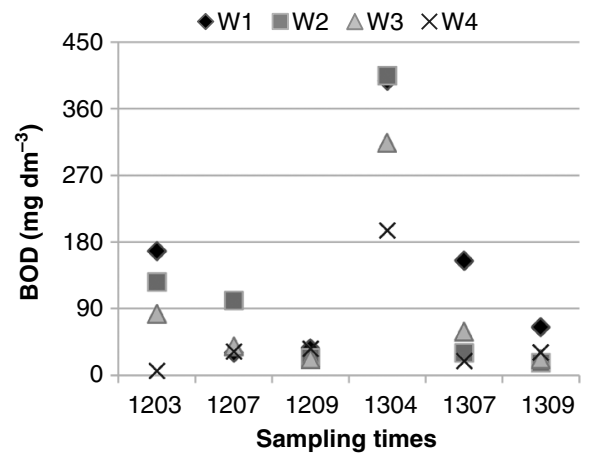

(c)

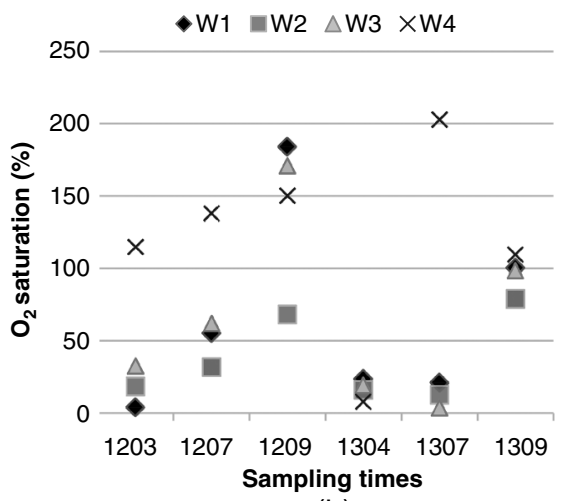

(b)

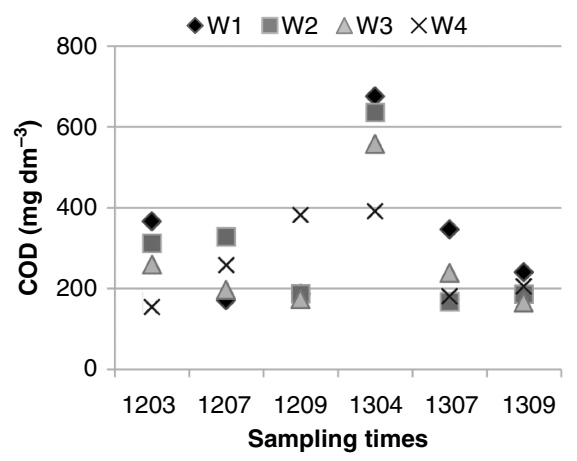

(d)

Figure 3. Oxygen balance of the lakes (see Figure 1) by sampling dates (a) dissolved oxygen, (b) oxygen saturation, (c) biological oxygen demand, and (d) chemical oxygen demand. The $\mathrm{X}$ axis shows the sampling dates, the first two numbers refers to the year, whereas the second the month.

The labels W1-W4 refer to the sampling type (W: water) and sites (1-4: the studied lakes)

years. The oxygen saturation values (Figure $3 \mathrm{~b}$ ) were mostly above $100 \%$ in BT4 during the studied period. In 2012, oxygen saturation values increased during the storage, whereas in 2013 due to the wet spring and summer months it stayed low and reached excellent quality just by the beginning of autumn. Until the beginning of spring, dissolved oxygen levels and oxygen saturation reached the level of "excellent water quality" with one exception: BT2 in September 2012, which also reached "good mesotrophic water quality" according to the standards. The BOD and COD values (Figure $3 \mathrm{c}$ and $3 \mathrm{~d}$ ) were similar and higher in lakes BT1-BT3, whereas lower in BT4 in connection with the supply of oxygen in the water of the lakes. Both BOD and COD values decreased throughout the storage period, especially in case of lakes BT1 and BT2. In 
April 2013, COD and BOD values were nearly 2 times higher than the other sampling times. This can be explained by the inland water flood that might had washed organic matter into the lake system from the surrounding agricultural area. However, in the following summer months, both values decreased. The COD values were decreasing through both years from spring to the end of summer in all lakes, except in BT4 in 2012, when COD was higher each time by approximately $100 \mathrm{mg} \mathrm{dm}^{-3}$. The initial BOD value was in average fivefold higher than the values at the end of the storage time, but even after this improvement, the biological oxygen demand of the lakes still qualified the environment as "heavily polluted" compared with the quoted standards. By the end of the 6-month long storage period, values of the COD dropped by half or more on average, but this storage time was not enough to improve the water quality.

Several nitrogen forms of the lake water affecting the microbial activity were measured throughout the two studied years (Figure $4 a-4 d$ ). The values of ammonium and total inorganic nitrogen were nearly identical that indicates that the amount of other inorganic nitrogen forms (e.g., nitrite and nitrate) was negligible in the lake system. The trends of changes of the ammonium and total inorganic nitrogen values were the same in both years; the relatively high and divergent values detected in the lakes in spring became similar and very low in autumn in all four lakes. The change of the organic nitrogen values was the opposite; in both years and in all lakes relatively low values were measured in the spring, and an increase was detected by the autumn. It suggests that inorganic nitrogen turned into organic nitrogen by conversion to microbial biomass. The total nitrogen values also showed an increasing trend, especially in the case of the largest open water surface lakes BT1 and BT4 where strong proliferation of cyanobacteria was observed by microscopy during the storage period in 2012. Probably, the nitrogen-fixing activity of these microbes may have also contributed to the increase of total nitrogen values of the lakes. In spring 2013, similar values were detected to the previous years. Conversely, relatively low values of total nitrogen and total organic nitrogen were detected in summer and autumn in 2013, probably due to the decrease in the abundance and activity of cyanobacteria following the flushing effect of flood, which was as well confirmed by microscopic analysis. In most of the cases, ammoniumnitrogen values fit the standards for "excellent water quality" by the end of summer. Nitrite and nitrate levels were not directly measured, although from the total inorganic nitrogen and ammonium-nitrogen values it is possible to estimate their levels in the studied lake system. According to these findings, all values fit into the category of "excellent water quality" throughout the whole studied period. 


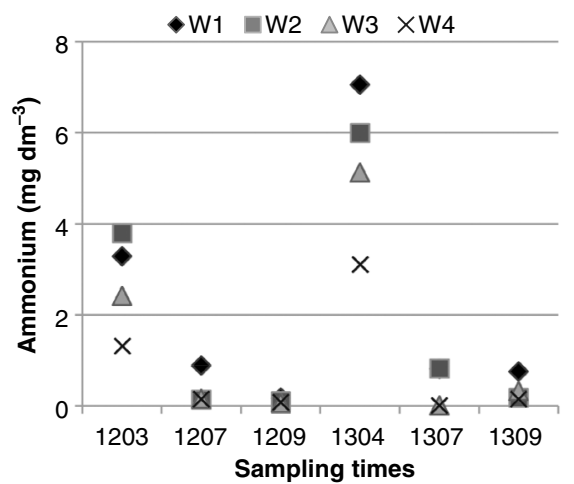

(a)

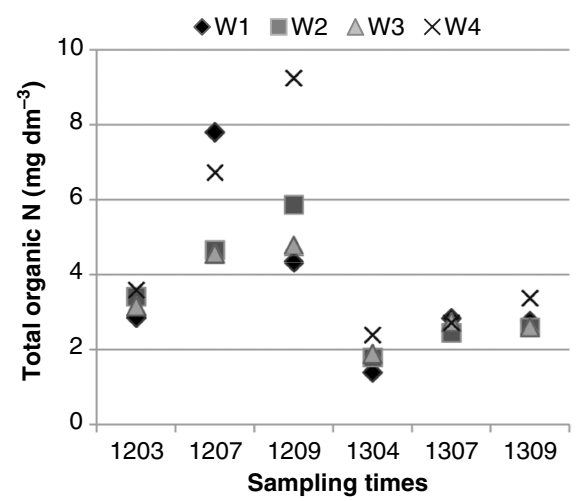

(c)

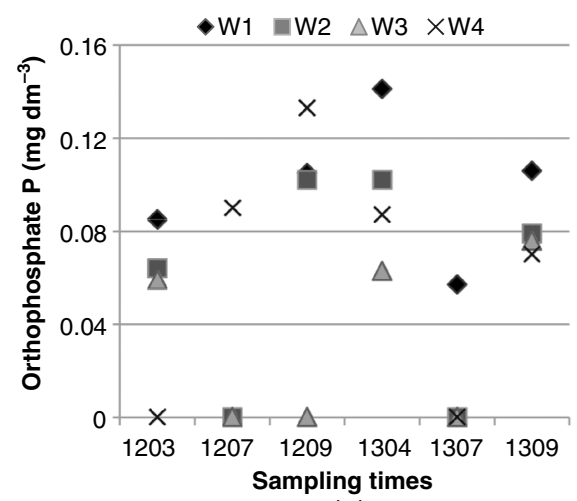

(e)

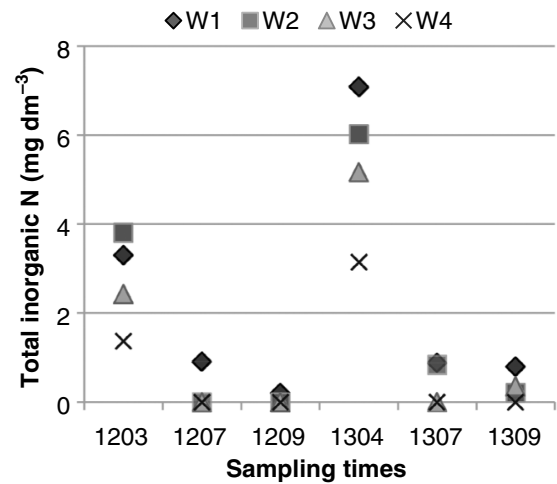

(b)

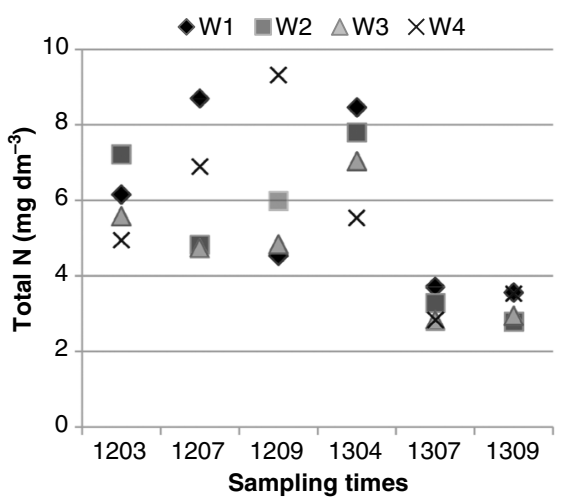

(d)

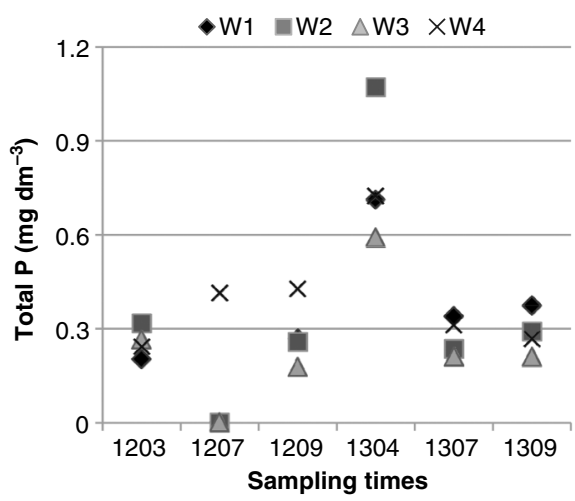

(f)

Figure 4. Nitrogen and phosphorus balance (a) ammonium ion, (b) total inorganic nitrogen, (c) total organic nitrogen, (d) total nitrogen, (e) orthophosphate phosphorus, and (f) total phosphorus of the lakes (see Figure 1) by sampling dates. The $\mathrm{X}$ axis shows the sampling dates, the first two numbers refers to the year, whereas the second the month. The labels W1-W4 refer to the sampling type (W: water) and sites (1-4: the studied lakes) 
In the two studied years, the changes of orthophosphate and total phosphorus values opposite trends - increasing in 2012, whereas decreasing in 2013 - were observed during the storage period (Figure 4e and 4f). Differences between the lakes were larger in the case of the orthophosphate than total phosphorus values in both years. Throughout the followed time period, total phosphorus values mostly stayed around the "good mesotrophic water quality" During the summer of 2013, all lakes fell under "excellent water quality" by orthophosphate levels.

Concentrations of phenols and phenol derivatives (measured as total phenol content) were relatively high in spring, however, their concentrations greatly decreased during the storage period, especially in BT1 and BT2 (Figure 5a). Phenol values were usually higher in lake BT1 than in lake BT4, indicating the presence of a phenol gradient in the flow direction of the water toward the output. By autumn, the phenol values became consistently low in all lakes of the system. The changes of total phenol concentrations were in accordance with the rising temperature suggesting that increasing bacterial activity could be responsible for the phenol degradation in the lake system. Until the end of summer, the total phenol concentration decreased far below the regulatory thresholds. It is also interesting that in spring 2013, the total phenol values were more than twice as high as in the previous spring, possibly due to the resuspension of particulates from the sediment. Following the flood in 2013, the whole lake system was drained off that caused disturbances in the lake system. Nevertheless, after the elevated levels detected in April, the phenol concentration decreased below the regulatory thresholds again by September proving that microbial communities were able to adapt to the higher pollutant concentrations with higher metabolic activity. Phenol concentration decreased by the end of the storage period, therefore the water quality changed from between "good mesotrophic" and "sufficient to excellent."

The changes of $\mathrm{pH}$ values were congruent in the two studied years: from early spring to late summer, the $\mathrm{pH}$ values in the whole system elevated by 0.5 approximately, reaching $\mathrm{pH}$ 9.5-10 that qualifies it as polluted water (Figure 5b). The $\mathrm{pH}$ was constantly alkaline in both studied years and all lakes (the highest in lake BT4). The conductivity values changed in a similar way in all lakes of the system; they increased parallel with the rise of the temperature, which lead to an increased evaporation during the summer period (Figure 5c). The conductivity values imply high initial salt concentration that increased further during the storage period. However, the rate of the increase of salinity was different in the two studied years, especially in lake BT4; in the more arid year 2012 the values nearly doubled, whereas in the wetter year 2013 conductivity change during the storage period was slight. In addition, in 2013 the differences among the lakes were negligible. In comparison with the surrounding rivers, the produced geothermal 


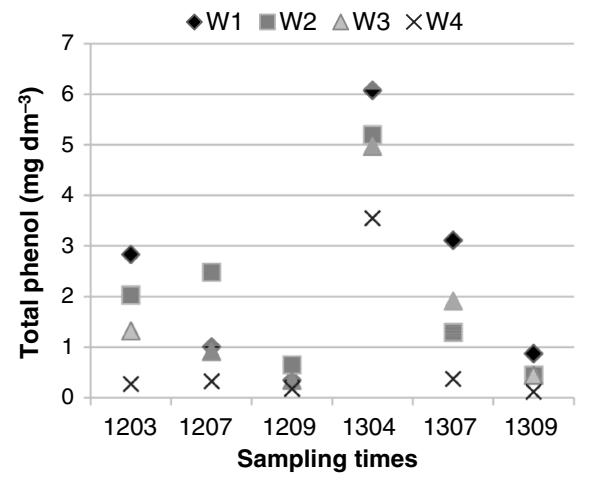

(a)

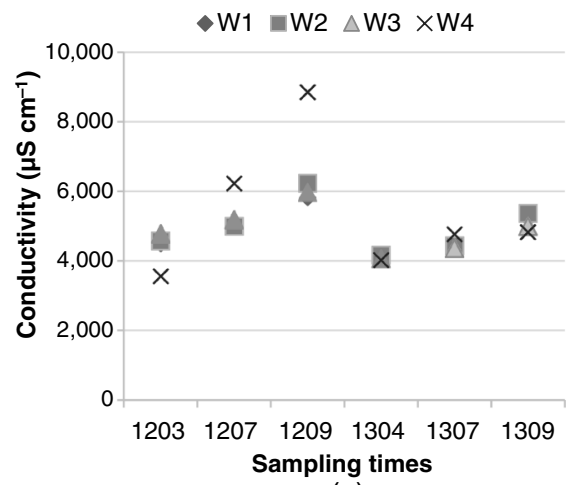

(c)

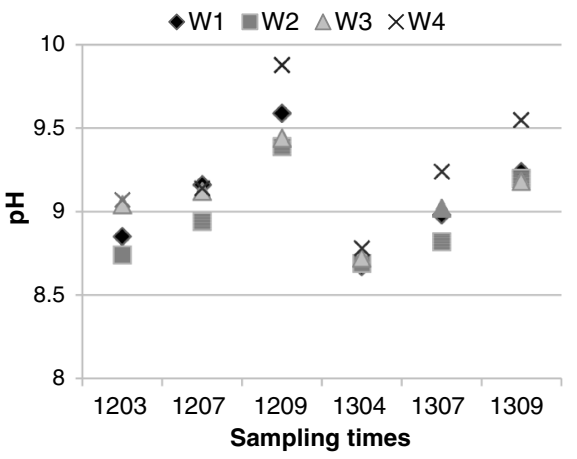

(b)

Figure 5. Other physical and chemical parameters (a) total phenol concentration, (b) $\mathrm{pH}$, (c) conductivity of the water bodies of the lakes (see Figure 1) by sampling dates. The X axis shows the sampling dates, the first two numbers refers to the year, whereas the second the month. The labels W1-W4 refer to the sampling type (W: water) and sites (1-4: the studied lakes)

water is of particularly high salt content, which consists almost exclusively of sodium bicarbonate [1]. The lakes - by the conductivity values - are qualified as "heavily polluted water."

Therefore, the major risk factor for this kind of thermal water disposal is the increase of salt concentration due to the evaporation during the storage period. It means that at the end of the storage period, the conductivity and $\mathrm{pH}$ values of the used thermal water become higher than in the beginning of the storage. Unfortunately, the high salt concentration of a reservoir lake to be redirected to natural water bodies is a problem because of the lack of available and efficient methods in salt removal technology. Thus, in many cases the redirected stored water is diluted before it reaches the recipient water body. 
$D G G E$

Fingerprinting methods like DGGE - although they were mostly replaced by next-generation sequencing methods - are still cost-effective and quick solutions to compare the spatial and temporal alterations of microbial communities and still widely used when in need to compare numerous timepoints and habitats [13-15].

Temporal and spatial changes in the structure of bacterial communities were followed by DGGE according to the sample types (water and sediment). The unweighted pair group method with arithmetic mean (UPGMA) dendrograms (Figures 6 and 7) were constructed on the basis of the number and position of bands (representing bacterial taxa) in the different lanes (representing the samples).

According to the position of the discrete bands in the gel, the bacterial communities of the water samples showed $40 \%-70 \%$ similarity to each other, suggesting a uniform distribution of the dominant planktonic organisms throughout the whole reservoir system. On the dendrogram (Figure 6), bacterial communities of the inflow samples markedly differed from the lake water samples. The primary clustering of the lake water bacterial communities could be observed according to the sampling times, which suggests that the changes of the bacterial communities were mainly influenced by the weather (Figure $2 a$ and $2 b$ ). The different temperature and precipitation conditions of the 2 years were reflected in the changes of bacterial community structures, as well. For example, the summer samples formed clusters with the spring samples in 2012, whereas with the autumn samples in 2013. This could be due to the flood and drainage in spring 2013 that favored the emergence of microorganisms from the catchment area of the lakes. However, as soon as the lakes were refilled with used thermal water following the flood, the bacterial community structure typical for the reservoir system was restored in summer and autumn 2013. Water samples from the lake system formed distinct groups in each season of both years; and bacterial communities from BT2 and BT3 lakes showed the highest similarity to each other, whereas samples from BT1 and BT4 were the most different.

In case of bacterial communities from sediment samples, no clear grouping could be revealed according to the sampling times (Figure 7). However, the relatively high similarities between the lakes BT2 and BT3 were also characteristic. In addition, the grouping of the summer sediment samples was similar to those of the water samples in both years.

According to the results obtained from the examination of the water quality and bacterial community structures of the water and sediment of the reservoir system, the lakes (BT1 and BT4) situated at the greatest distance from each other were the most dissimilar. This lead to the conclusion that despite the fact that lakes 


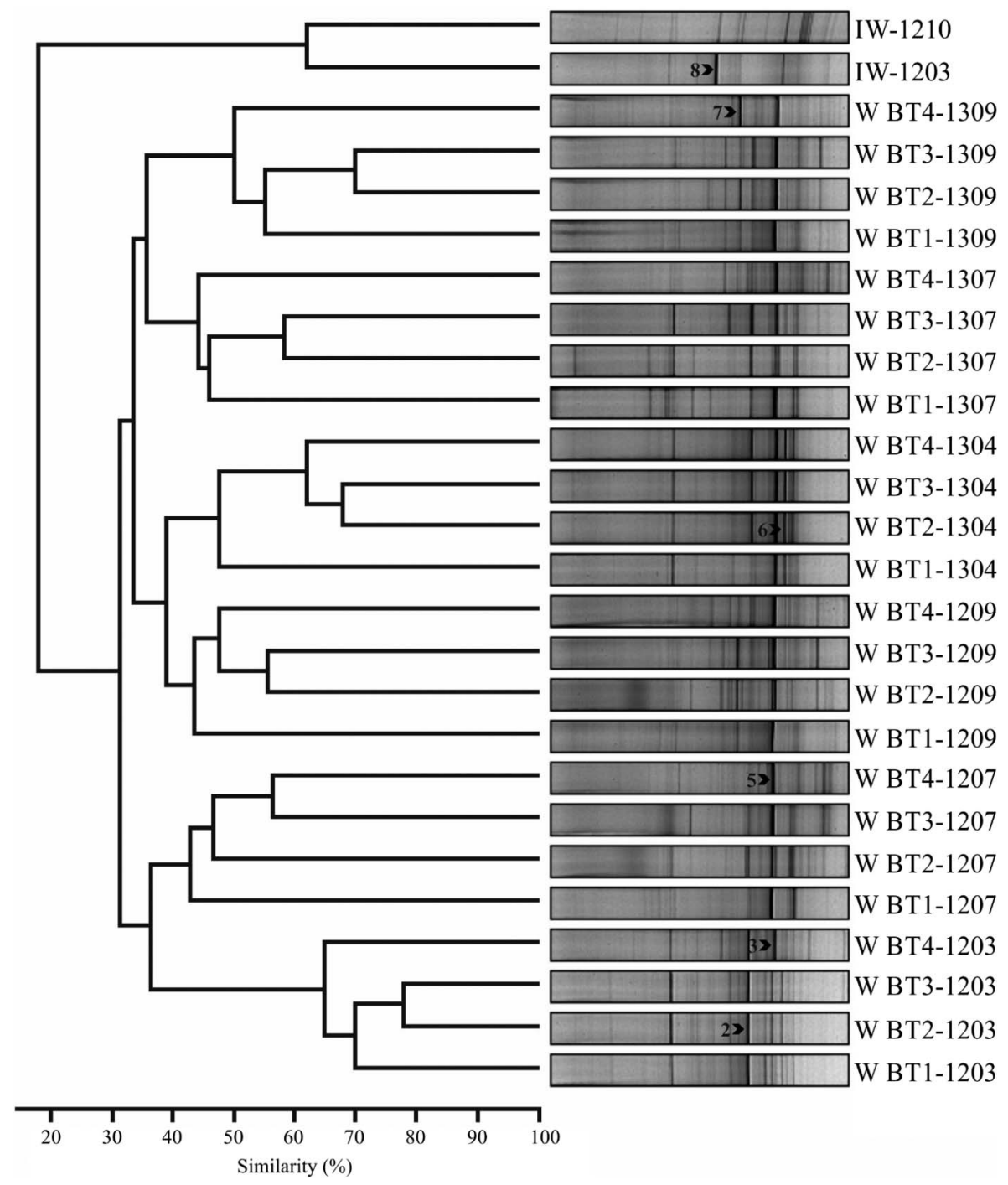

Figure 6. UPGMA dendrogram constructed on the basis of DGGE patterns of the bacterial communities of the examined water samples collected in 2012 and 2013. The arrows mark the excised bands and the numbers indicate the numbering of the individual bands.

of the system are interconnected and filled gravitationally, during the storage period there is a detectable difference between the sampling sites where the used thermal water enters the first lake (BT1) and where the stored thermal water reaches the 


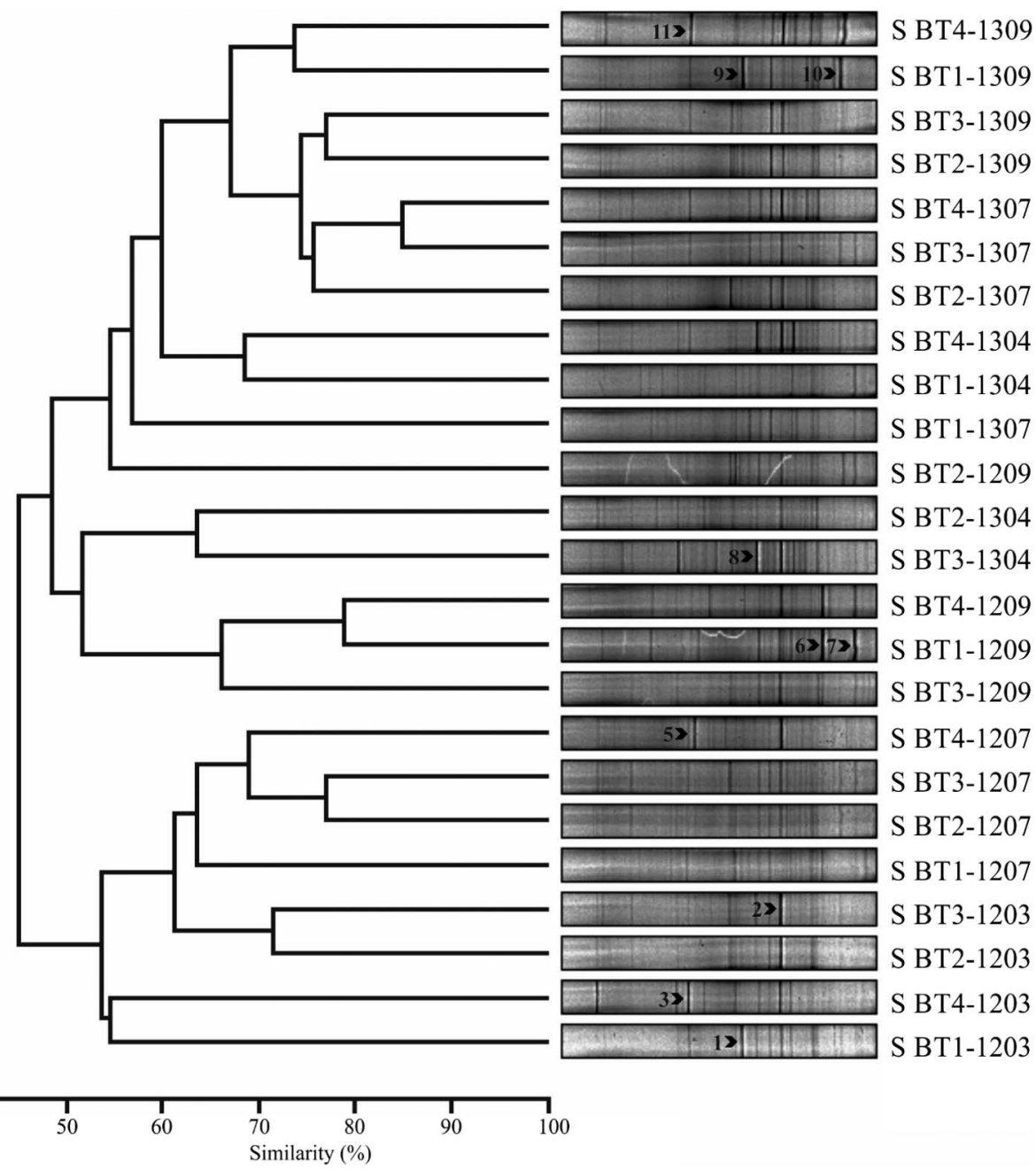

Figure 7. UPGMA dendrogram constructed on the basis of DGGE patterns of the bacterial communities of the examined sediment samples collected in 2012 and 2013. The arrows mark the excised bands and the numbers indicate the numbering of the individual bands.

outlet of the system (BT4). The revealed dissimilarity between the lakes BT1 and BT4 may be related to the different nature of the lakes (BT2 and BT3) located between them. Due to the almost complete reed coverage, lake BT2 may contribute to the filtering of the lake water coming from the lake BT1, whereas lake BT3 can reduce the flow rate toward the lake BT4 because of its greater water depth. 
The amplification and sequencing of the DNA excised from the discrete bands resulted in ten different phylotypes (Table I) out of which only 3 could be identified at species level (they showed higher than $97 \%$ similarity to described species).

Arthrospira indica identified by DGGE could be observed in the water samples by microscopy as well. In the sediment samples, it was presented in most of the lanes (Figure 7), which confirm its constant occurrence during the storage period, while it was detected in the water of lake BT4 mainly in summer (Figure 6). Ballot et al. [16] also isolated this multicellular helixshaped trichome forming cyanobacterium from Kenyan saline-alkaline lakes similar to this studied lake system. Olguín et al. [17] published details about using Arthrospira species to treat anaerobic effluents from pig wastewater with great efficiency; in removal of ammonium-nitrogen was in the range of $84 \%-96 \%$ and phosphate removal in the range of $72 \%-87 \%$. The role of this genus in oxygen-producing photosynthesis is obvious and explains why Arthrospira can be one of the most successful members of the bacterial communities in a temporal reservoir lake system, which has high initial ammonium concentrations.

Table I. Nearest published taxonomic groups to the sequences obtained from the excised DGGE bands (see Figures 6 and 7), respectively

\begin{tabular}{llr}
\hline Phylum/band & \multicolumn{1}{c}{ Nearest published relative by EzTaxon } & Similarity \% (bp/bp) \\
\hline $\begin{array}{l}\text { Cyanobacteria } \\
\text { W5, S2 }\end{array}$ & Arthrospira indica (AY575931) & $100(385 / 385)$ \\
W7, S1, S9 & Anabaenopsis elenkinii (AM773307) & $99.48(381 / 383)$ \\
Deferribacterales & & \\
W8 & Uncultured bacterium clone (FJ638568) & $99.78(446 / 447)$ \\
Proteobacteria & & \\
Alphaproteobacteria & & \\
W6 & Pseudorhodobacter wandonensis (JN247434) & $97.2(382 / 393)$ \\
Betaproteobacteria & & \\
S6, S7 & Azoarcus buckleii (AJ315676) \\
W2, S8 & Hydrogenophaga taeniospiralis (AF078768) & $94.47(393 / 416)$ \\
Deltaproteobacteria & & $96.29(441 / 458)$ \\
S10 & Desulfuromusa succinoxidans (X79415) \\
S10 & Uncultured bacterium clone (JQ738939) & \\
Incertae sedis & & $78.03(341 / 437)$ \\
S3, S11 & Uncultured bacterium clone (AB513440) \\
S5 & Uncultured bacterium clone (FJ717262) & $97.64(455 / 466)$ \\
\hline Note: Similarity is based &
\end{tabular}

Note: Similarity is based on the partial sequence of 16S rRNA gene via the EzTaxon-e server and the NCBI database. 
Another member detected in the water and sediment samples from the reservoir system was the species Anabaenopsis elenkinii. According to the DGGE pattern of the water samples (Figure 6), bands corresponding to Anabaenopsis were presented only in September 2013 in all but BT3 lake. In the sediment samples, sequences from two distinct bands were found to be Anabaenopsis (Figure 7). A. elenkinii is a heterocystous, nitrogen-fixing cyanobacterium commonly found in tropical, subtropical, and temperate alkaline-saline water bodies [18].

Members of the genus Hydrogenophaga were also presented in both sample types, the sequences showed the highest similarity to the species Hydrogenophaga taeniospiralis. This facultatively chemolithoautotrophic organism can grow heterotrophically and is able to utilize a wide range of carbon sources and can perform denitrification [19-21]. The phylotype related to this species was the most abundant in the spring water and sediment samples from both years and lakes, but small populations were presented almost the whole year.

Representatives of the species Pseudorhodobacter wandonensis [22], an aerobic, purple, and non-sulfur bacterium (which does not contain bacteriochlorophyll $a$ ) were found exclusively in the water samples from April 2013.

The spring in 2013 was unusual because of the inland water flood. It made necessary to drain off and refill the lakes that could have resulted in the disturbance and appearance of bacterial species (e.g., Hydrogenophaga and Pseudorhodobacter) in relatively high abundance.

\section{Conclusions}

The use of the reservoir system - consisting of four gravitationally interconnected lakes - proved to be an adequate solution for the temporary storage of geothermal water from the aspects of most of the studied parameters. By the end of the storage period, the water quality was appropriate according to the standard values of dissolved oxygen, oxygen saturation, inorganic and organic nitrogen, orthophosphate, and phenol concentrations. Therefore, lake water could be redirected from the system to a natural surface water. Most of the favorable changes in the water quality were not affected by the weather conditions (e.g., flood) or disturbance in the environment (e.g., drainage of the lakes), except for the $\mathrm{pH}$ and conductivity values, which constantly increased during the storage period. Nevertheless, their values were acceptable in the receiving large stream due to the high degree of dilution. Microbial communities - the structures of which changed both in time and space - might play a decisive role (e.g., by decrease the ammonium and phenol concentrations) in the improvement of 
the water quality of the reservoir system. However, a more detailed examination needs to reveal the archaeal and bacterial community composition and explore the role of prokaryotes in the decomposition of phenolic compounds of the used thermal waters.

\section{Conflict of Interest}

The authors declare no conflict of interest.

\section{References}

1. Németh, A., Szirányi, B., Krett, G., Janurik, E., Kosáros, T., Pekár, F., Márialigeti, K., Borsodi, A. K.: Prokaryotic phylogenetic diversity of Hungarian deep subsurface geothermal well waters. Acta Microbiol Immun Hung 61, 363-377 (2014).

2. Varsányi, I., Matray, J. M., Ó Kovács, L.: Hydrogeochemistry in two adjacent areas in the Pannonian Basin (Southeast-Hungary). Chem Geol 156, 25-39 (1999).

3. László, Z., Hodúr, C.: Purification of thermal wastewater by membrane separation and ozonation. Desalination 206, 333-340 (2007).

4. Szanyi, J., Kovács, B.: Utilization of geothermal systems in South-East Hungary. Geothermics 39, 357-364 (2010).

5. Bodvarsson, G.: Thermal problems in the siting of reinjection wells. Geothermics 1, 63-66 (1972).

6. Pekár, F.: The Basics and Environmental Impacts of Geothermal Energy Utilization. A geotermikus energiahasznosítás alapjai és környezeti hatásai. Mezőgazda Kiadó, Budapest, 2008, pp. 195-198 (in Hungarian).

7. MET: Region-specific weather data from the webpage of the Hungarian Meteorological Services. Available at http://met.hu/eghajlat/magyarorszag_eghajlata/eghajlati_visszatekinto/ elmult_honapok_idojarasa/

8. Lane, D. J.: 16S/23S rRNA sequencing. In: Stackebrandt, E. Goodfellow, M. (eds): Nucleic Acid Techniques in Bacterial Systematics. Wiley, New York, 1991, pp. 115-175.

9. Nübel, U., Engelen, B., Felske, A., Snaidr, J., Wieshuber, A., Amann, R. I., Ludwig, W., Backhaus, H.: Sequence heterogeneities of genes encoding 16S rRNAs in Paenibacillus polymyxa detected by temperature gradient gel electrophoresis. J Bacteriol 178, 5636-5643 (1996).

10. Muyzer, G., de Waal, E. C., Uitterlinden, A. G.: Profiling of complex microbial populations by denaturing gradient gel electrophoresis analysis of polymerase chain reaction-amplified genes coding for 16S rRNA. Appl Environ Microb 59, 695-700 (1993).

11. Kim, O. S., Cho, Y. J., Lee, K., Yoon, S. H., Kim, M., Na, H., Park, S. C., Jeon, Y. S., Lee, J. H., Yi, H., Won, S., Chun, J.: Introducing EzTaxon: A prokaryotic 16S rRNA gene sequence database with phylotypes that represent uncultured species. Int J Syst Evol Microbiol 62, 716-721 (2012).

12. Altschul, S. F., Madden, T. L., Schaffer, A. A., Zhang, J., Zhang, Z., Miller, W., Lipman, D. J.: Gapped BLAST and PSI-BLAST: A new generation of protein database search programs. Nucleic Acids Res 25, 3389-3402 (1997). 
13. Araya, R., Tani, K., Takagi, T., Yamaguchi, N., Nasu, M.: Bacterial activity and community composition in stream water and biofilm from an urban river determined by fluorescent in situ hybridization and DGGE analysis. FEMS Microbiol Ecol 43, 111-119 (2003).

14. Chen, M., Chen, F., Zhao, B., Wu, Q. L., Kong, F.: Seasonal variation of microbial eukaryotic community composition in the large, shallow, subtropical Taihu Lake, China. Aquat Ecol 44, 1-12 (2010).

15. Zeng, J., Yang, L., Li, J., Liang, Y., Xiao, L., Jiang, L., Zhao, D.: Vertical distribution of bacterial community structure in the sediments of two eutrophic lakes revealed by denaturing gradient gel electrophoresis (DGGE) and multivariate analysis techniques. World J Microb Biot 25, 225-233 (2009).

16. Ballot, A., Dadheech, P. K., Krienitz, L.: Phylogenetic relationship of Arthrospira, Phormidium and Spirulina strains from Kenyan and Indian water bodies. Algol Stud 113, 37-56 (2004).

17. Olguín, E. J., Galicia, S., Mercado, G., Pérez, T.: Annual productivity of Spirulina (Arthrospira) and nutrient removal in a pig wastewater recycling process under tropical conditions. J Appl Phycol 15, 249-257 (2003).

18. Ballot, A., Dadheech, P. K., Haande, S., Krienitz, L.: Morphological and phylogenetic analysis of Anabaenopsis abijatae and Anabaenopsis elenkinii (Nostocales, Cyanobacteria) from tropical inland water bodies. Microb Ecol 55, 608-618 (2008).

19. Kämpfer, P., Schulze, R., Jäckel, U., Malik, K. A., Amann, R., Spring, S.: Hydrogenophaga defluvii sp. nov. and Hydrogenophaga atypica sp. nov., isolated from activated sludge. Int J Syst Evol Microbiol 55, 341-344 (2005).

20. Lalucat, J., Pares, R., Schlegel, H. G.: Pseudomonas taeniospiralis sp. nov., an R-bodycontaining hydrogen bacterium. Int J Syst Bacteriol 32, 332-338 (1982).

21. Willems, A., Busse, J., Goor, M., Pot, B., Falsen, E., Jantzen, E., Hoste, B., Gillis, M., Kersters, K., Auling, G., de Ley, J.: Hydrogenophaga, a new genus of hydrogen-oxidizing bacteria that includes Hydrogenophaga flava comb. nov. formerly Pseudomonas flava), Hydrogenophaga palleronii (formerly Pseudomonas palleronii), Hydrogenophaga pseudoflava (formerly Pseudomonas pseudoflava and "Pseudomonas carboxydoflava"), and Hydrogenophaga taeniospiralis (formerly Pseudomonas taeniospiralis). Int J Syst Bacteriol 39, 319-333 (1989).

22. Lee, M. H., Lee, S. Y., Jung, Y. T., Park, S., Yoon, J. H.: Pseudorhodobacter wandonensis sp. nov., isolated from wood falls, and emended description of the genus Pseudorhodobacter. Int J Syst Evol Microbiol 63, 1479-84 (2013). 